\title{
Distances of Palmar Flexion Creases (Haustra Digiti) and Digital Formulae in Right and Left Handed People
}

\author{
Distancia de los Pliegues de Flexión Palmar (Haustra Digiti) \\ y Fórmulas Digitales en Personas Diestras y Zurdas
}

Rengin Kosif*; Murat Diramali* \& Seda Sertel ${ }^{* *}$

KOSIF, R.; DIRAMALI, D. \& SERTEL, S. Distances of palmar flexion creases (haustra digiti) and digital formulae in rigth and left handed people. Int. J. Morphol., 33(1):173-177, 2015.

SUMMARY: Digital flexion creases are one of the external anatomical landmarks in the hand. In this study, we measured and compared the distances between the digital skin creases (haustra digiti) in the fingers of right-handed and left-handed individuals. We also recorded the digital formulae. No significant difference was detected between left and right-handed females and left and right handed males on distance of skin creases $(\mathrm{p}>0.05)$. No difference was detected on haustra digiti of the right handed females their own hands. Females who use their left hand had a significantly longer $(\mathrm{p}=0.48)$ distal haustra digiti segment on their right second finger than that of their left hand. However, no significant difference was detected between male individuals on their left and right hand all haustra digiti segments. The rate of hand digital formulae of $3>4>2>5>1$ was $78.12 \%$ in left-handed females, $66.7 \%$ in left-handed males, $54.54 \%$ in right-handed females, and $78.57 \%$ in right-handed males. Our study has contributed to the literature on the morphological asymmetry of left-handed females.

KEY WORDS: Handedness; Palmar flexion creases; Digital formulae.

\section{INTRODUCTION}

The shapes and segments of hands and fingers constitute an important indicator of individual developmental characteristics in fetal and postnatal periods (Brons et al., 1990; Budarick et al., 1981). External anatomical landmarks in the hand are important for anatomy and surgery (Strauch \& de Moura, 1985; Lin et al., 1989; Hazani et al., 2008). External anatomical landmarks of the hand as bone prominences and creases help to localize its joints and other structures during the clinical examination (Buryanov \& Kotiuk, 2010). Digital flexion creases are one of the external anatomical landmarks in the hand.

Digital flexion crease one of the grooves on the palmar surface of a finger, at the level of an interphalangeal joint (Kimura \& Kitagawa). The digital flexion creases represent the location of firmer attachment of the skin to the underlying structures and correspond to regions where accelerated growth does not take place. Their name reflects the functional relationship of these creases to the flexion movements of the fingers but does not necessarily relate to their developmental origin. There has been some disagreement regarding the origin of digital (and palmar) creases. The first hypothesis is that hand creases develop secondary to flexion movements of the developing hand. This is supported by studies of abnormal crease patterns in malformed hands and by the correspondence of palmar and digital creases to the location of underlying joints. It has been demonstrated that digital flexion creases begin to appear between 7 and 9 weeks of gestational age while spontaneous flexion of the digits does not occur until 11.5 weeks of gestation (Kimura \& Kitagawa). This would seem to refute the hypothesis that the flexion creases arise secondary to functional movements of the digits. The second hypothesis is that the flexion creases arise independently of fetal palm movement and are genetically determined. The presence of extra and missing digital creases in individuals with normal joint anatomy supports this (Kamath et al., 2002).

Digital skin creases are located consistently proximal to their corresponding distal interphalangeal joints, lying at mean distances of 7-7.8 mm proximal to the joint. Middle digital flexion creases also are located consistently proximal

\footnotetext{
* Department of Anatomy, Faculty of Medicine, Abant Izzet Baysal University, Bolu, Turkey.

** Kemal Demir School of Physical Therapy and Rehabilitation, Abant Izzet Baysal University, Bolu, Turkey.
} 
to their corresponding proximal interphalangeal joints with mean distance ranging from 1.6-2.6 $\mathrm{mm}$ proximal digital skin creases are consistently located distal to their corresponding metacarpophalangeal joints with mean values ranging from 14.4-19.6 $\mathrm{mm}$ distal to the joint. In the thumb the interphalangeal joint flexion crease is located proximal to the interphalangeal joint by a mean distance of $2.2 \mathrm{~mm}$, where as the metacarpophalangeal flexion crease is found to directly over the metacarpophalangeal joint (Doyle \& Botte, 2003).

Phalanx morphology was studied previously (Buryanov \& Kotiuk; Marzke et al., 2007). But, no topographical measurement of the distance between digital creases has been carried out yet. In this study, we measured and compared the distances between the digital skin creases in the fingers of right-handed and left-handed individuals. We also recorded the digital formulae of right-handed and left-handed individuals.

\section{MATERIAL AND METHOD}

The participants included 164 students in the 18-22 age group studying at Abant Izzet Baysal University. Measurements were performed on a total of 87 female students ( 55 right-handed and 32 left-handed) and a total of 77 males (56 right-handed and 21 left-handed) (Table I). Only fully right-handed and fully left-handed individuals were included in the study. Right and left preferences were detected in hand and foot use. Hand preference was identified by ten questions in a modified version of Oldfield hand preference inventory (Buryanov \& Kotiuk).

Middle and distal digital creases are close to interphalangeal joints. But the distance from the proximal digital crease to the middle digital crease is not equal to the proximal phalanx length (Doyle \& Botte). Such distances will be termed as haustra digiti in this study (Fig. 1).

To measure the distance of haustra digiti, the fingers were flexed and the distance of the haustra digiti was measured laterally from the crease ends (Fig. 2) (Doyle \& Botte). The hands' digital formulae were also recorded (Fig. 3) (Lewis, 1996).

Measurements were performed by a same person using Baker Digital Caliper with a reading sensitivity of $0.01 / 0.0005 \mathrm{~mm}$. The recorded results were analyzed by 11.0 SPSS software. Student t-test was employed for all intergroup comparisons.

Table I. Study group.

\begin{tabular}{llll}
\hline & Female & Male & Total \\
\cline { 2 - 4 } Right Handed & 55 & 56 & 111 \\
Left Handed & 32 & 21 & 53 \\
Total & 87 & 77 & 164 \\
\hline
\end{tabular}




\section{RESULTS}

ANOVA test was conducted to determine the hausra digiti differences among left handed females, right handed females, left handed males and right handed males. Bonferroni was used as post-hoc test. No significant difference was detected between left and right-handed females and left and right handed males on haustra digiti $(\mathrm{p}>0.05)$.

Moreover haustra digiti differences on right and left handed females among their own hand fingers were also measured by student t-test. No difference was detected on haustra digiti of the females who use their right hand. Females who use their left hand had a significantly longer $(\mathrm{p}=0.48)$ distal haustra digiti segment $(24.42 \pm 1.65 \mathrm{~mm})$ on their right second finger than that of their left hand $(25.06 \pm 1.45 \mathrm{~mm})$ (Table II). However, no significant difference was detected between male individuals on their left and right hand all haustra digiti segments (Table III).

The rate of hand digital formulae of $3>4>2>5>1$ was $78.12 \%$ in left-handed females, $66.7 \%$ in left-handed males, $54.54 \%$ in right-handed females, and $78.57 \%$ in righthanded males. The hand digital formulae of $3>2>4>5>1$ was found with the highest rate in right-handed females $(45.46 \%)$ and with the lowest rate in right-handed males $(21.43 \%)$ (Fig. 4).

Table II. Right- left handed female haustra digiti means.

\begin{tabular}{lcccc}
\hline & \multicolumn{2}{c}{ Left handed $(\mathbf{m m})$} & \multicolumn{2}{c}{ Right handed (mm) } \\
\cline { 2 - 5 } & Left hand & Right hand & Left hand & Right hand \\
\hline $1 \mathrm{p}$ & $32.58 \pm 3.08$ & $32.65 \pm 3.34$ & $32.05 \pm 3.57$ & $32.23 \pm 3.13$ \\
$1 \mathrm{~d}$ & $31.11 \pm 1.74$ & $30.80 \pm 2.01$ & $30.72 \pm 1.88$ & $30.96 \pm 1.98$ \\
$2 \mathrm{p}$ & $22,52 \pm 1,87$ & $22.61 \pm 1.91$ & $22.75 \pm 2.49$ & $22.82 \pm 2.05$ \\
$2 \mathrm{~m}$ & $20.43 \pm 1.73$ & $20.65 \pm 1.76$ & $20.27 \pm 1.97$ & $20.45 \pm 2.11$ \\
$2 \mathrm{~d}$ & $24.42 \pm 1.65^{*}$ & $25.06 \pm 1.45^{*}$ & $24.42 \pm 1.64$ & $24.36 \pm 1.49$ \\
$3 \mathrm{p}$ & $25.17 \pm 2.20$ & $25.86 \pm 2.03$ & $22.05 \pm 2.59$ & $25.42 \pm 2.48$ \\
$3 \mathrm{~m}$ & $23.89 \pm 2.06$ & $23.60 \pm 1.77$ & $23.74 \pm 2.31$ & $23.38 \pm 2.18$ \\
$3 \mathrm{~d}$ & $25.42 \pm 1.43$ & $25.54 \pm 1.58$ & $25.34 \pm 1.72$ & $25.09 \pm 1.42$ \\
$4 \mathrm{p}$ & $22.14 \pm 2.37$ & $22.47 \pm 2.14$ & $21.76 \pm 2.66$ & $21.98 \pm 2.66$ \\
$4 \mathrm{~m}$ & $21.98 \pm 2.17$ & $21.58 \pm 1.72$ & $21.66 \pm 2.37$ & $21.40 \pm 2.70$ \\
$4 \mathrm{~d}$ & $25.10 \pm 1.92$ & $25.11 \pm 1.71$ & $24.74 \pm 1.81$ & $24.71 \pm 1.68$ \\
$5 \mathrm{p}$ & $17.72 \pm 2.43$ & $18.09 \pm 2.82$ & $17.48 \pm 2.24$ & $17,63 \pm 2,04$ \\
$5 \mathrm{~m}$ & $15.77 \pm 1.84$ & $15.30 \pm 1.67$ & $15.19 \pm 2.20$ & $15.28 \pm 2.22$ \\
$5 \mathrm{~d}$ & $22.84 \pm 1.03$ & $22.64 \pm 1.52$ & $22.47 \pm 1.73$ & $22.71 \pm 1.51$ \\
\hline
\end{tabular}

$*=\mathrm{p}<0.05$

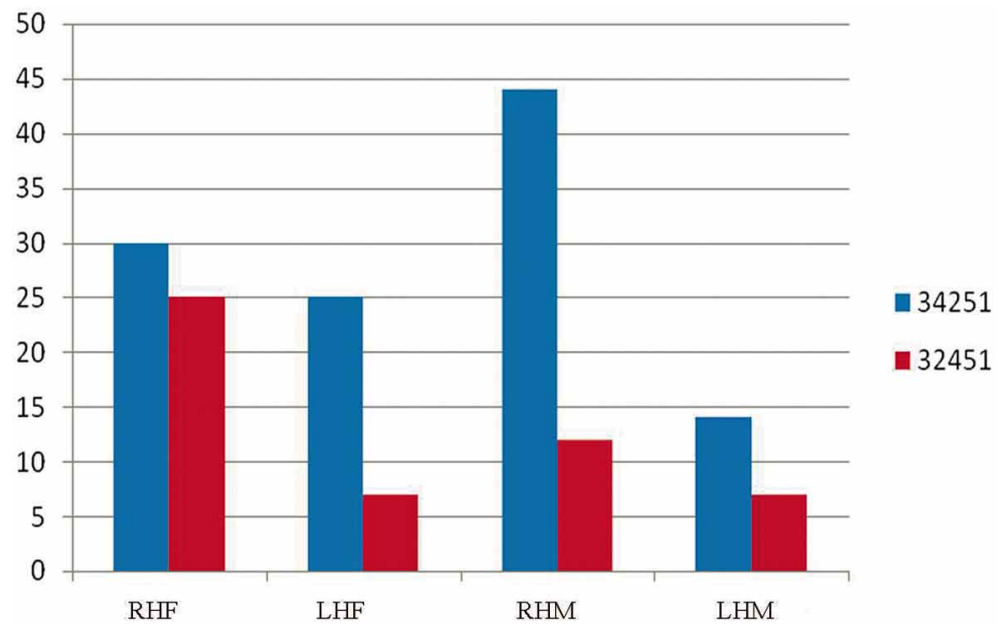

Fig. 4. Hand digital formulae distribution. RHF= Right Handed Female; $L H F=$ Left Handed Female; RHM= Right Handed Male; LHM= Left Handed Male. 
Table III. Right- left handed male haustra digiti means.

\begin{tabular}{lcccc}
\hline & \multicolumn{2}{c}{ Left handed $(\mathbf{m m})$} & \multicolumn{2}{c}{ Right handed $(\mathbf{m m})$} \\
\cline { 2 - 5 } & Left hand & Right hand & Left hand & Right hand \\
\hline $1 \mathrm{p}$ & $34.52 \pm 4.56$ & $35.04 \pm 4.46$ & $34.44 \pm 3.84$ & $34.97 \pm 3.84$ \\
$1 \mathrm{~d}$ & $33.67 \pm 1.94$ & $34.06 \pm 3.32$ & $34.44 \pm 2.15$ & $34.42 \pm 2.48$ \\
$2 \mathrm{p}$ & $25.15 \pm 2.16$ & $25.51 \pm 2.81$ & $24.66 \pm 2.03$ & $24.35 \pm 2.41$ \\
$2 \mathrm{~m}$ & $21.72 \pm 1.93$ & $21.71 \pm 2.10$ & $21.98 \pm 2.39$ & $22.02 \pm 2.01$ \\
$2 \mathrm{~d}$ & $27.21 \pm 1.79$ & $27.20 \pm 1.30$ & $26.97 \pm 1.65$ & $26.81 \pm 2.11$ \\
$3 \mathrm{p}$ & $27.08 \pm 2.35$ & $27.74 \pm 2.40$ & $27.24 \pm 2.43$ & $27.23 \pm 2.53$ \\
$3 \mathrm{~m}$ & $25.68 \pm 2.00$ & $25.45 \pm 2.06$ & $25.37 \pm 2.43$ & $24.93 \pm 2.29$ \\
$3 \mathrm{~d}$ & $28.20 \pm 1.48$ & $28.16 \pm 1.10$ & $27.69 \pm 1.82$ & $27.05 \pm 1.73$ \\
$4 \mathrm{p}$ & $23.25 \pm 2.62$ & $23.68 \pm 2.20$ & $23.70 \pm 2.28$ & $23.98 \pm 2.65$ \\
$4 \mathrm{~m}$ & $22.87 \pm 1.82$ & $23.17 \pm 2.29$ & $23.05 \pm 2.21$ & $23.00 \pm 2.01$ \\
$4 \mathrm{~d}$ & $27.69 \pm 1.57$ & $27.80 \pm 1.30$ & $27.62 \pm 1.76$ & $27.79 \pm 1.85$ \\
$5 \mathrm{p}$ & $18.59 \pm 2.52$ & $19.39 \pm 1.70$ & $19.04 \pm 2.40$ & $19.11 \pm 2.64$ \\
$5 \mathrm{~m}$ & $16.09 \pm 1.38$ & $15.82 \pm 2.38$ & $16.42 \pm 2.09$ & $16.93 \pm 2.59$ \\
$5 \mathrm{~d}$ & $25.36 \pm 1.26$ & $24.96 \pm 1.34$ & $25.05 \pm 1.78$ & $25.43 \pm 1.65$ \\
\hline
\end{tabular}

\section{DISCUSSION}

Given the hand's adaptability, the functional significance of digital and metacarpal formulae is not to seek the best hand type for certain tasks, but rather to determine which hands are relatively disadvantaged in performing those tasks. Furthermore, when not ideally matched, what taskspecific compensating mechanisms are invoked in the hand and arm, and what is the likely concomitant pathology. Taken together, nine different combinations of digital and metacarpal formulae are possible, allowing a greater degree of discernment between hand forms. The digital formulae of $3>4>2>5>1$ was detected in males with a rate of $69.6 \%$, while females had the formulae of $3>2>4>5>1$ with a rate of $44 \%$ (Lewis). In our study, we found the hand digital formulae of $3>4>2>5>1$ by $78.12 \%$ in left-handed females, by $66.70 \%$ in left-handed males, by $54.54 \%$ in right-handed females, and by $78.57 \%$ in right-handed males.

The presence of hand asymmetry in the right-handed and the left-handed has been shown in some studies. CRH musicians exhibited a reduced degree of hand skill asymmetry in comparison to CRH nonmusicians (Jäncke $e t$ al., 1997). Among chronic renal disease patients, the second metacarpal showed the right metacarpal to be larger than the left second metacarpal, both in right-handed individuals and left-handed individuals (Garn et al., 1976).

Outcomes in the human second metacarpal, confirm and extend previous research documenting structural asymmetries and limb dominance and are consistent with the concept of articular constraint. They also suggest a morphological signal through which functional asymmetry associated with handedness in fossil hominins may be investigated (Lazenby et al., 2008).
The lenght of the 5th finger is longer among left-handed females than right handed females (Kosif \& Diramali, 2012). In right-handers the mean value of right hand 2D:4D is higher (insignificant) than the value of left hand 2D:4D . The pattern of asymmetry is reverse in left-handers: higher mean value of 2D:4D (significant) in the left hand as compared to 2D:4D in the right hand (Stoyanov et al., 2009; Manning \& Peters, 2009). The length of the index finger relative to that of the ring finger, the 2D:4D ratio of neither the left nor the right hand was related to handedness (Beaton et al., 2011).

Comprising samples right-, mixed- and left-handers, the atd-angle, the a-b ridge count and the hypothenar radial arch were investigated, the asymmetry of both quantitative traits differentiated into directional (DA) and fluctuating (FA) one. Except for the FA of the a-b ridge count in females, which decreased significantly from right handed to left handed, the trends observed in the relations between the investigated dermatoglyphic values and handedness were not significant (Karev, 2011).

Haustra digiti have never been compared in any study. As a result, the distal haustra digiti in the left right second fingers of left-handed females were found to be significantly lengthy when compared to their left hands, a result which was not observed in the right-handed. The hand digital formulae of $3>2>4>5>1$ is less frequent in left-handed females. Our study has contributed to the literature on the morphological asymmetry of left-handed females. Phalanx lengths are important in hand surgery and helps prosthesis adjustments. Any defect or imperfection, particularly shortness, in the hand can be treated by state-of-the-art surgical techniques. The relationships in morphometric measurements could be useful for surgical interventions (Aydinlioglu et al., 1998). In firing a firearm, the precise placement of the mid-portion of the distal phalanx of the trigger finger/index finger on the firearm trigger 
is critical to accurate shooting (http). Since morphological measurements are valuable for hand surgery, the asymmetry in the left-handed should be considered both in surgery and in prosthesis preparation.

Note: «Haustra Digiti» which is an anatomic term used in this study was used only by myself for the first time. I suggested that it can be used as «Parmak Bogumlari=Kosif Bogumlari» as in Turkish.

KOSIF, R.; DIRAMALI, D. \& SERTEL, S. Distancia de los pliegues de flexión palmar (haustra digiti) y fórmulas digitales en personas diestras y zurdas. Int. J. Morphol., 33(1):173-177, 2015.

RESUMEN: Los pliegues digitales de flexión constituyen unos de los puntos de referencia anatómicos externos en la mano. En este estudio se midieron y compararon las distancias entre los pliegues digitales de la manos (haustra digiti) de individuos diestros y zurdos. También se registraron las fórmulas digitales. No se detectaron diferencias significativas entre mujeres zurdas y diestras y tampoco entre varones diestros y zurdos en relación a la distancia de los pliegues digitales $(p>0,05)$. No se detectaron diferencias en el haustra digiti de las mujeres diestras. Las mujeres que utilizaban su mano izquierda tenían una diferencia significativamente mayor $(\mathrm{p}=0,48)$ en el segmento distal del segundo dedo, comparado con el de la mano derecha. Sin embargo, no se detectaron diferencias significativas entre los individuos de sexo masculino en sus manos izquierda y derecha, a nivel de todos los segmentos de los haustra digiti. La fórmula digital $3>4>2>5>1$ se encontró en 78,12\% de las mujeres zurdas, en el 66,7\% de hombres zurdos, en el 54,54\% de mujeres diestras, y en el 78,57\% de hombres diestros. Nuestro estudio ha contribuido a la literatura sobre la asimetría morfológica de los pliegues digitales de las mujeres zurdas.

PALABRAS CLAVE: Lateralidad; Pliegues de flexión palmar; Fórmulas digitales.

\section{REFERENCES}

Aydinlioglu, A.; Akpinar, F. \& Tosun, N. Mathematical relations between the lengths of the metacarpal bones and phalanges: surgical significance. Tohoku J. Exp. Med., 185(3):209-16, 1998.

Beaton, A. A.; Rudling, N.; Kissling, C.; Taurines, R. \& Thome, J. Digit ratio (2D:4D), salivary testosterone, and handedness. Laterality, 16(2):136-55, 2011.

Brons, J. T.; van Geinjn, H. P.; Bezemer, P. D.; Nauta, J. P. \& Arts N. F. The fetal skeleton; ultrasonographic evaluation of the normal growth. Eur. J. Obstet. Gynecol. Reprod. Biol., 34(1-2):21-36, 1990.

Budarick, N. E.; Pretorius, D. H.; Johnson, D. D.; Tartal, M. K.; Lou, K. U. \& Nelson, T. R. Three-dimensional ultrasound examination of the fetal hands: normal and abnormal. Ultrasound Obstet. Gynecol., 12(4):227-34, 1998.

Buryanov, A. \& Kotiuk, V. Proportions of Hand Segments. Int. J. Morphol., 28(3):755-8, 2010.

Doyle, J. R. \& Botte, M. J. Surgical anatomy of the hand and upper extremity. Philadelphia, Lippincott Williams \& Wilkins, 2003. pp.533-4.
Garn, S. M.; Mayor, G. H. \& Shawam, H. A. Paradoxical bilateral asymmetry in bone size and bone mass in the hand. Am. J. Phys. Anthropol.,45(2):209-10, 1976.

Hazani, R.; Engineer, N. J.; Zeineh, L .L. \& Wilhelmi, B. J. Assessment of the distal extent of the A1 pulley release: a new technique. Eplasty, $8: \mathrm{e} 44,2008$

Jäncke, L.; Schlaug, G. \& Steinmetz, H. Hand skill asymmetry in professional musicians. Brain Cogn., 34(3):424-32, 1997.

Kamath, B. M.; Loomes, K. M.; Oakey. R. J. \& Krantz. I. D. Supernumerary digital flexion creases: an additional clinical manifestation of Alagille syndrome. Am. J. Med. Genet., 112(2):171$5,2002$.

Karev, G. B. Three palmar dermatoglyphic traits and their asymmetry in Bulgarian right-, mixed- and left-handers. Anthropol. Anz., 68(3):291-307, 2011

Kimura, S. \& Kitagawa, T. Embryological development of human palmar, plantar, and digital flexion creases. Anat. Rec., 216(2):191-7, 1986.

Kosif, R. \& Diramali, M. Comparison of all hand digit length ratios in left- and right-handed individuals. Turk. J. Med. Sci., 42(3):545$52,2012$.

Lazenby, R. A.; Cooper, D. M.; Angus, S. \& Hallgrímsson, B. Articular constraint, handedness, and directional asymmetry in the human second metacarpal. J. Hum. Evol., 54(6):875-85, 2008.

Lewis, S. Morphological aspects of male and female hands. Ann. Hum. Biol., 23(6):491-4, 1996

Lin, G. T.; Amadio, P. C.; An, K. N. \& Cooney, W. P. Functional anatomy of the human digital flexor pulley system. J. Hand. Surg., 14(6):94956, 1989.

Manning, J. T. \& Peters, M. Digit ratio (2D:4D) and hand preference for writing in the BBC Internet Study. Laterality, 14(5):528-40, 2009.

Marzke, M. W.; Shrewsbury, M. M. \& Horner, K. E. Middle phalanx skeletal morphology in the hand: can it predict flexor tendon size and attachments? Am. J. Phys. Anthropol., 134(2):141-51, 2007.

Strauch, B. \& de Moura, W. Digital flexor tendon sheath: an anatomic study. J. Hand Surg., 10(6 Pt. 1):785-9, 1985.

Stoyanov, Z.; Marinov, M. \& Pashalieva, I. Finger length ratio (2D:4D) in left- and right-handed males. Int. J. Neurosci., 119(7):1006-13, 2009.

Correspondence to:

Dr. Rengin Kosif

Department of Anatomy, Faculty of Medicine

Abant Izzet Baysal University

Gölköy Campus 14280

Bolu

TURKEY

Email: rengink@yahoo.com

Received: 13-05-2014

Accepted: 27-10-2014 